\title{
Discussion on the Teaching Reform of Building Architecture
}

\author{
SUN Yu \\ College of Engineering \\ Ocean University of China \\ Qingdao, P.R.China \\ cqdoucsuny@163.com
}

\author{
YIN Xing \\ College of Engineering \\ Ocean University of China \\ Qingdao, P.R.China \\ yinxing1995@hotmail.com
}

\begin{abstract}
Building Architecture is a basic specialty course of Civil Engineering, and it has significance for the subsequent course and students' career. However, the present teaching results for this course are not satisfactory. The traditional teaching method desiderates to be reformed. This paper analyses the existing problems in the current teaching method, such as ignoring architectural design, students' lack of initiative and disjoint of textbook and engineering. After that, this paper summarizes a set of effective methods of teaching reform of Building Architecture, including introducing Case Method and BIM technology into teaching, field observation, putting emphasis on curriculum design, and so on. These methods help students adapt to the requirement of society and provide teachers with reference to the teaching reform of this course.
\end{abstract}

Keywords-teaching reform; civil engineering; Building Architecture; architectural design; construction design

\section{INTRODUCTION}

Building Architecture is a basic specialty course that helps civil engineering students with understanding architectural ideas and processes, the construction and detail of buildings, and their relationships with other relevant expertise, especially those with structural expertise. [1]

The content of Building Architecture course is extensive and comprehensive, including architectural function, architectural art, environmental planning, engineering technology, engineering economy and many other aspects.

This course mainly includes four parts: design of civil building, construction of civil building, design of industrial building and construction of industrial building. The requirements of this course are to understand the basic theories and methods of civil \& industrial building design and to master the basic theories and methods of civil \& industrial building construction.

Building Architecture is a course with strong comprehensiveness and practicality. The traditional teaching methods cannot be able to meet the requirement of society. Therefore, this paper analyzes the existing problems in the teaching of Building Architecture, and proposes some method of teaching reform, so as to be able to refer to the teaching reform of Building Architecture.

\section{The Existing Problems In The CurRent TeACHING METHOD}

\section{A. Ignore the content of architectural design}

In engineering practice, civil engineering is closely related to architecture, and the learning conditions of architecture will affect the work efficiency in the future directly.

In the actual teaching, however, the two majors of civil engineering and architecture are too emphasis on their professional characteristics. Take civil engineering as the example, civil engineering lays special emphasis on mechanics, basic principles of structures and civil engineering construction, but this major lacks of attention to architectural design. [2]

Today's complex buildings requires close teamwork between civil engineers and architects, but in the work, civil engineers and architects often have contradictions, the reason may be that civil engineers lack of architectural education, and they cannot understand the architects' design concept.

\section{B. Students' lack of initiative}

The course of Building Architecture has many characteristics, such as abstract theories, various contents and so on. The civil \& industrial building design part has many abstract theories, which are difficult for students to understand. As for civil \& industrial building construction, there are a number of contents that need students to memorize. Thus, students often feel dull and have difficulty understanding and grasping during the study period. Students often learn it by rote to pass the final examination and lack of initiative of studying; leading students fail to grasp the knowledge.

\section{Disjoint of textbook and practical engineering}

It is well-known that the speed of revision of textbooks is far behind the pace of development of the practical engineering. There are lots of construction technologies and architectural construction which taught in textbooks has long abandoned by practical engineering.

Take waterproof construction as an example, in practical engineering, the traditional "three floors of tarred felt and four floors of tar" and other water proof asphalt-felt methods have been replaced by high polymer water-proof sheet, but many 
textbooks of Building Architecture are still teaching these building constructions.

In addition, many new concepts, new construction technique and new material are not mentioned by textbooks, such as building energy conservation, green building, ecological building, building industrialization and so on. This will lead students to spend a lot of time on learning outdated knowledge, and this situation is harmful to students' career development as well as the development of society. Thus, it should be changed.

\section{The TeAching Reform Of BuILding Architecture}

\section{A. Introduce Case Method into teaching}

In order to overcome the shortcomings of too many knowledge points and lack of continuity, which hinder students construct the integrated knowledge system, teachers can introduce Case Method into teaching.

Specifically, teachers can teach some actual engineering cases during the teaching period. To begin with the actual architecture design ideas, then teachers introduce the contents of foundation works, the walls, the stairs, the flooring, the roof, the doors and windows, the waterproof, the insulation and so on, rather than the tradition of lecturing in the order of chapters. [3]

TABLE I.

COMPARISON OF TEACHING ORDER

\begin{tabular}{|c|c|c|}
\hline $\begin{array}{c}\text { Teaching } \\
\text { order }\end{array}$ & The order of textbooks & $\begin{array}{c}\text { The order of actual } \\
\text { engineering cases }\end{array}$ \\
\hline 1 & The flooring and roof & The foundation works \\
\hline 2 & The walls & The flooring \\
\hline 3 & The surface finish & The walls \\
\hline 4 & The foundation works & The surface finish \\
\hline 5 & The stairs & The stairs \\
\hline 6 & The doors and windows & The roof \\
\hline 7 & The waterproof & The doors and windows \\
\hline 8 & The insulation & The waterproof \\
\hline 9 & & The insulation \\
\hline
\end{tabular}

This teaching method not only helps students form integrated knowledge system of Building Architecture, but also build structural concepts and systems for students, which help them with their sequential courses' learning, such as Design of Building Structures, Civil Engineering Construction and HighRise Building Structure. [4][5]

\section{B. Introduce BIM technology into teaching}

In recent years, the technology of BIM is getting more and more attention. BIM (Building Information Modeling) is a digital representation of physical and functional characteristics of a facility. A BIM is a shared knowledge resource for information about a facility forming a reliable basis for decisions during its life-cycle; defined as existing from earliest conception to demolition. [6]
BIM technology is going to bring a technological revolution in the construction industry, and the Chinese construction industry is also aware of the importance of BIM technology, they are promoting the application of BIM technology in the construction field actively.

However, Chinese construction industry encounters some obstacles in the promotion of developing BIM technology, and the main factors is that the pace of training talents cannot keep up with the demands of construction industry. Therefore, to promote the development of BIM technology, we must do the corresponding training from students. The stage of university is the key state to develop this expertise.

In the teaching process of Building Architecture, teachers can reform the teaching method combined with BIM technology.

With the help of AUTODESK REVIT (a BIM software), teachers can create a Walkthrough and export it to images and animations, which can be presented in class. The Walkthrough breaks through the limitations of time and space, and promote the students' perceptual knowledge, stir up students' interest of this course.

What's more, teachers can also use BIM technology to make courseware. The traditional multimedia courseware is mainly made by imagines, which are not intuitive and not easy to understand. Using BIM technology to make 3D multimedia courseware not only provides students with a more intuitive learning method, making teaching period lifelike and visualized, but also help students understand the BIM technology better.

At the same time, teachers can introduce some basic knowledge of BIM technology to students, so that students can experience the advantage of three-dimensional visualization and be guided to apply BIM technology to engineering practice.

In general, it is an effective method to help students comprehend BIM technology that drawing three-dimensional model with BIM technology during the teaching period.

\section{Lead students to observe the building construction}

It is necessary to link theory with practice. As the building construction taught by textbooks is abstract and difficult to understand by students, teachers can lead students to observe the university's teaching buildings, library, dormitories and laboratories' workshop, etc. Mainly observe those buildings' architectural design idea and building construction, this will help students establish the concept of form, space and order, evolving students’ imaginal thinking.

After that, students are asked to conduct their own investigation and complete the investigation report. The form of the investigation report can be flexible, such as summing up the types and characteristics of the wall decoration of the buildings, and draw profile drawings. This will not only enable students to make more in-depth understanding of Building Architecture, but also improve students' drawing ability. 


\section{Introduce new developments in civil engineering}

At present, with the rapid development of China's construction technology, a variety of new building materials, new building construction and new concepts emerge in an endless stream, but the contents of textbooks are far behind the engineering practice. As mentioned earlier, the majority new buildings have insulation construction, but some Housing Architecture textbooks are not involved in the content, besides, green building, ecological building and building industrialization are rarely involved in textbooks.

Thus, teachers can ask students to read related journal regularly and share knowledge with classmates in order to help students grasp the trends of the development of civil engineering, and broaden the students' horizons of the vanguard, besides teachers can also share frontier and developments in civil engineering through QQ group and WeChat group, which improves the quality of teaching effectively.

\section{E. Increase students' understanding of Architecture}

In order to improve the students' understanding of the Architecture, in addition to the basic content of building construction aspects, teachers should also focus on the aspects of architecture, architectural history and architectural design; strengthen the education of architectural culture. [7]

Teachers should make full use of multimedia-assisted teaching and improve students' intuitive sense and interest of this course, let students learn more able the architectural style of Chinese and foreign buildings. By this method, students can enhance the understanding of architectural art further and fully understand the intention of architectural design.

In the architectural design part of this course, the method of analysis of architectural examples can be used by teachers. Since architectural design is divided into plan design, elevation design and profile design with three aspects, teachers can consider these three aspects as a whole. Starting with the selection of building structure, then teach the conceptual design, after that, teachers teach the composition principle and aesthetic principles of architectural design, so that the whole building in to an organic whole, which not only to meet the requirement of using functions, but also design an ideal architectural configuration. And finally follow the fundamental principle of architecture: durability, utility and beauty.

\section{F. Put emphasis on Building Architecture Curriculum Design}

As an important part of practice teaching in Civil Engineering, the Building Architecture Curriculum Design plays an important role in improving students' comprehensive quality and cultivating students' innovative ability. Thus, teachers should put emphasis on Building Architecture Curriculum Design. [8][9]

In Ocean University of China, the Building Architecture Curriculum Design is scheduled for the summer semester, although the time for curriculum design is abundant, students are rusty at knowledge due to the summer vacation, and the curriculum design cannot achieve the expected results normally.
Many students put off drawing their architectural drawings until the last minute and plagiarize the assignments.

Thus it can be seen that the reform of Building Architecture Curriculum Design is an indispensable part of the reform of Building Architecture. It is a question worth to explore that how to improve students' ability of creativity, imagination and expression through curriculum design.

Firstly, teachers distribute the assignment books before the summer vocation, so that students can prepare for the curriculum design.

Secondly, in order to enhance students' teamwork capabilities, the flexible form of group discussion is used in the curriculum design.

Thirdly, encourage students take full advantage of BIM technology. In practice, many students spend much time on modifying drawing, rather than the conceptual design. In fact, this is not a unique problem for students, even experienced engineers have similar problems, but with the help of BIM software, plan design, elevation design, profile design and 3D model can associate with each other. From this point, complete curriculum design with BIM software can save students' time and let them spend more time on the understanding of architectural knowledge, rather than the endless modifying drawings.

Finally, teachers arouse more interest and motivation in students by selecting subject reasonably. The subjects of curriculum design should be those students can contact in daily life, such as teaching buildings of school, high-rise apartment and office buildings. The kindergartens and villas are a little difficult for students, and may result in act blindly. In a word, the aim of selection of subject is that students have a high enthusiasm for this subject and can take the initiative to think, which can improve learning effect significantly.

\section{CONCLUDING REMARKS}

With an ever-increasing global population that continues to shift to urban areas will require a number of outstanding civil engineers, but the civil engineer's world in future will be even more challenging than today. According to The VISION for Civil Engineering in 2025 by ASCE (American Society of Civil Engineers), the civil engineer should be knowledgeable, skillful and embrace creativity attitudes conductive to effective professional practice. From this point, those methods of Building Architecture's teaching reform above will help students a lot in their careers.

In order to stimulate the enthusiasm and initiative of students, a variety of teaching methods are applied during the reform of the course of Building Architecture. Those methods not only open up students' vision, but also cultivate their creative ability through adjustment and supplement of teaching content timely, make students adapt to the development of society and get good teaching effect. 


\section{REFERENCES}

[1] Tongji University, Xi'an University of Architecture and Technology, Southest University and Chongqing University, Building Architecture, 5th ed, Beijing: China Architecture \& Building Press, pp.1-2, 2016.

[2] HUANG Juan, "To emphasize on the course of housing lay the foundation of civil engineering”, Journal of Architectural Education in Institutions of Higher Learning, vol.39(2), pp.31-32, 2001.

[3] LÜ Yan, "Application of Case-oriented Teaching Method in Building Architecture Teaching”, Journal of Tianjin Chengjian University, vol.22(4), pp.312-314, 2016.

[4] Wang Yingzi, Xiong Guangjing, Kang Quanli, "Case Study on the 'Ability - Quality - Knowledge' Structure in Housing Architecture Curriculum syllabus and Teaching Practice”, Research in Higher Education of Engineering, vol.1, pp.155-158, 2010.
[5] SUN Chao-fa, "Topic-centered Teaching Pattern in Building Architecture Course”, Journal of Architectural Education in Institutions of Higher Learning, vol.18(4), pp.62-64, 2009.

[6] QI Yue, ZHANG Junhua, ZHAO Wenjun, "Reform of building architecture combined with BIM technology”, Journal of Architectural Education in Institutions of Higher Learning, vol.23(6), pp.147-149, 2014.

[7] HAN Yan-juan, ZHU Wen-zheng, "On the teaching of the course of building construction”, Journal of Architectural Education in Institutions of Higher Learning, vol.14(1), pp.54-56, 2005.

[8] Chen Yu, Du Yong, "Reach on housing architecture curricula design”, China Science and Technology Information, vol.23, pp.292-293, 2008.

[9] GUO Jing, "Study on the Reform of the Teaching Method on Building Architecture Curricula Design”, Journal of Architectural Education in Institutions of Higher Learning, vol.18(1), pp.113-115, 2009. 